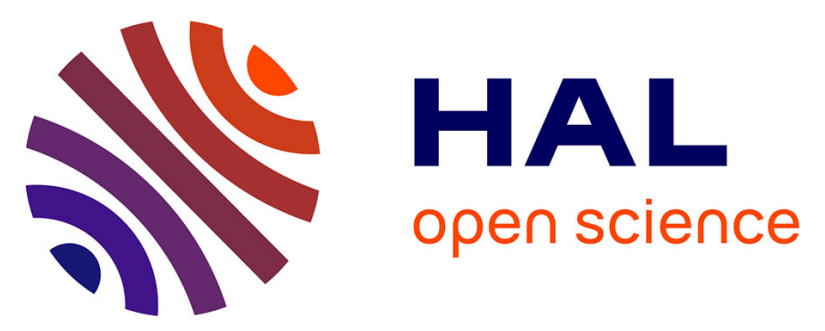

\title{
Synthesis, characterisation and electrochemical behaviour of some nickel(II) complexes with linear and tripodal tetradentate ligands derived from Schiff bases.
}

S. Djebbar-Sid, O. Benali-Baitich, Mustayeen A. Khan, G. Bouet.

\section{- To cite this version:}

S. Djebbar-Sid, O. Benali-Baitich, Mustayeen A. Khan, G. Bouet.. Synthesis, characterisation and electrochemical behaviour of some nickel(II) complexes with linear and tripodal tetradentate ligands derived from Schiff bases.. Synthesis and Reactivity in Inorganic and Metal-Organic Chemistry, 1997, 27 (8), pp.1219-1233. 10.1080/00945719708000259 . hal-03193551

\section{HAL Id: hal-03193551 \\ https://univ-angers.hal.science/hal-03193551}

Submitted on 11 Apr 2021

HAL is a multi-disciplinary open access archive for the deposit and dissemination of scientific research documents, whether they are published or not. The documents may come from teaching and research institutions in France or abroad, or from public or private research centers.
L'archive ouverte pluridisciplinaire HAL, est destinée au dépôt et à la diffusion de documents scientifiques de niveau recherche, publiés ou non, émanant des établissements d'enseignement et de recherche français ou étrangers, des laboratoires publics ou privés. 
SYNTH. REACT. INORG. MET.-ORG. CHEM., 27(8), 1219-1233 (1997)

\title{
SYNTHESIS, CHARACTERISATION AND ELECTROCHEMICAL BEHAVIOUR OF SOME NICKEL(II) COMPLEXES WITH LINEAR AND TRIPODAL TETRADENTATE LIGANDS DERIVED FROM SCHIFF BASES.
}

\author{
S. Djebbar-Sid ${ }^{\mathrm{a}}$, O. Benali-Baitich ${ }^{\mathrm{a}}$, M. A. Khan ${ }^{\mathrm{b}}$ and G. Bouet ${ }^{\mathrm{b}}$ \\ a Laboratoire de Chimie de Coordination, Institut de Chimie, \\ USTHB, BP 32, El Alia, Bab Ezzouar, Alger (Algérie) \\ b Laboratoire de Chimie de Coordination, Faculte de Pharmacie, \\ 16 Boulevard Daviers, F-49100 Angers, France
}

\section{ABSTRACT}

A number of new six-coordinate $\mathrm{Ni}(\mathrm{II})$ complexes with linear and tripodal tetradentate ligands having the general formula $\left.\left[\mathrm{Ni}_{(} \mathrm{H}_{2} \mathrm{~L}\right)\left(\mathrm{H}_{2} \mathrm{O}\right)_{2}\right] \mathrm{Cl}_{2} . \mathrm{xH}_{2} \mathrm{O}$ have been synthesized. Microanalysis, molar conductance, IR spectra, thermogravimetric analysis, magnetic measurements, and electronic spectra have been used to elucidate their structure. The experimental data show that the ligands are bonded in a non-deprotonated form and are coordinated in a tetradentate manner, the other axial sites being occupied by the aquo molecules. On the basis of electronic results it is concluded that tripodal ligands exert the strongest ligand field and the ligand substituents affect the ligand field strength which increases with the electron donating effect of the $\mathrm{R}$ group.

The electrochemical behaviour of the nickel(II) complexes was determined by cyclic voltammetry which shows that chelate structure, ligand geometry and electron donating effect of the ligand substituents are among the factors influencing the redox potentials of the complexes. Also, we note that the ligands used in the present study can stabilize both the nickel(I) and the nickel(III) states. 


\section{INTRODUCTION}

The investigation of the catalytic functions of nickel in biological systems has become a rapidly developing research area. To date, nickel has been identified as an integral component of a number of enzymes ${ }^{1}$. The biological activity of the nickel ion related to the electron transport is in some way dependent on the structural arrangement of the coordination sphere and the electronic environment of the ligand ${ }^{2}$. In a bioinorganic context there is much current interest in the use of nickel(II) complexes with Schiff bases ligands as models for biological systems ${ }^{3-5}$.

This paper describes the preparation of new nickel(II) complexes with tetradentate ligands derived from Schiff bases which are soluble in water, and the effects of substituents indirectly attached to the central ion, chelate structure and ligand geometry (linear $\mathrm{H}_{2} \mathrm{~L}^{1-3}$, Fig. 1, and tripodal $\mathrm{H}_{2} \mathrm{~L}^{4-6}$, Fig. 2) on the metal-ligand bonding character and on redox potentials of the complexes.

The compounds synthesized were characterized by microanalyses, conductivity and magnetic susceptibility measurements, TGA and spectral (IR and UV-Visible) studies. Based on the results obtained, tentative structures are proposed for the complexes

\section{EXPERIMENTAL}

\section{Analytical and Physical Measurements}

The elemental microanalyses were carried out at the Central Service of Analysis, CNRS Vernaison (France). Chlorine and water of hydration were determined by conventional methods as described by Vogel ${ }^{6}$. Melting points were measured using a digital melting point apparatus IA 9000. The conductometric measurements were carried out with a CD 810 Tacussel conductivitymeter. The IR spectra were recorded on a FTS-7 Biorad Fourier transform infrared spectrometer using KBr disks. Thermal analyses were carried out with a Goerz Metrawat-SE 120 apparatus. The electronic absorption spectra in solution were recorded on a Perkin Elmer Lamda 9 


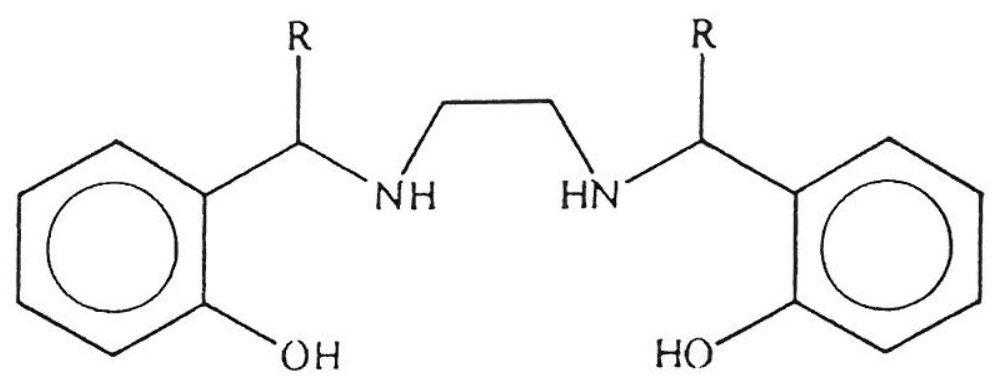

Fig. 1. Structure of Linear Ligands

$R=H: H_{2} L^{\prime} ; R=C_{3}: H_{2} L^{2} ; R=C_{2} H_{5}: H_{2} L^{3}$

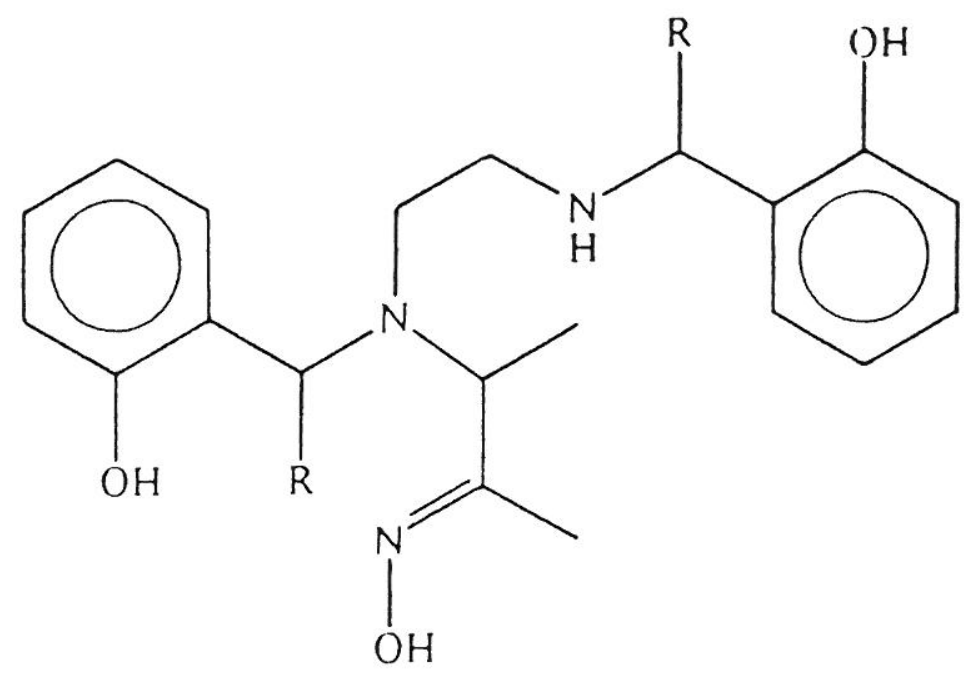

Fig. 2. Structure of Tripodal Ligands

$\mathrm{R}=\mathrm{H}: \mathrm{H}_{2} \mathrm{~L}^{4} ; \mathrm{R}=\mathrm{CH}_{3}: \mathrm{H}_{2} \mathrm{~L}^{5} ; \mathrm{R}=\mathrm{C}_{2} \mathrm{H}_{5}: \mathrm{H}_{2} \mathrm{~L}^{6}$

spectrometer using suprasil cells. Magnetic susceptibilities were obtained with a B-SU 10 Bruker magnetic balance using $\mathrm{Hg}\left[\mathrm{Co}(\mathrm{SCN})_{4}\right]$ as paramagnetic reference, and diamagnetic corrections were made using Pascal's constants. Electrochemical measurements were recorded with a Princeton Applied Research model 273 potentiostat-galvanostat. Cyclic voltammograms were obtained using a SEFRAMTGM 164 recorder. The working, counter and reference electrodes used were, respectively, a platinum wire, a platinum foil and a SCE (saturated calomel electrode). The SCE was separated from the test solution by a bridge filled with the solvent and supporting electrolyte which was tetrabutylammonium perchlorate (TBAP). The inert gas used was nitrogen. Coulometric measurements were made using a double circular platinum net as working electrode. The auxiliary and 
reference electrodes, the blank electrolyte solution and the inert gas were the same as in voltammetric measurements.

\section{Materials}

DMSO used for electrochemical measurements was dried by distillation over $\mathrm{CaH}_{2}$ or by storing over 4-Ä molecular sieves. All other chemical reagents and solvents used in the preparations were Fluka p.a. products and used without further purification.

\section{Preparation of Ligands}

The preparation and characterisation of the ligands $\mathrm{H}_{2} \mathrm{~L}^{1}-\mathrm{H}_{2} \mathrm{~L}^{6}$ used in the present investigation have previously been communicated ${ }^{7}$.

\section{Preparation of Complexes}

An aqueous solution of $\mathrm{NiCl}_{2}, 6 \mathrm{H}_{2} \mathrm{O}(0.24 \mathrm{~g}, 1 \mathrm{mmole})$ was added dropwise to the ligand $\left(0.4 \mathrm{~g}, 1 \mathrm{mmole}\right.$ ) dissolved in $10 \mathrm{~mL}$ of a $\mathrm{EtOH}-\mathrm{H}_{2} \mathrm{O}$ solution ( $25 \%$ by volume). The mixture was heated at $40^{\circ} \mathrm{C}$ with constant stirring until it was concentrated. The precipitate was filtered and washed successively with water and ethanol-water stable at room temperature and soluble in water and in common organic solvents. The complexes were purified by recristalization from diethyl ether solution.

\section{RESULTS AND DISCUSSION}

The analysis of the complexes are consistent with the stoichiometry proposed and are summarized in Table I. The conductivity data of the complexes in DMF at $10^{-3} \mathrm{M}$ indicate that they are $1: 2$ electrolytes compounds ${ }^{8}$, suggesting that two chlorides are outside the metal coordination sphere. Unfortunately, we could not grow any single crystal suitable for X-ray crystallographic studies.

\section{Infrared Spectra}

The IR spectra of all the complexes (Table II) show bands around 3300, 3200 and $3100 \mathrm{~cm}^{-1}$ which may be assigned to the simultaneous presence of coordinated 


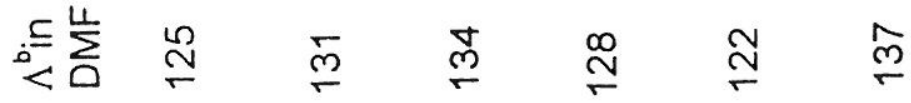

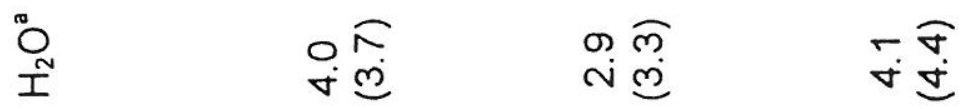

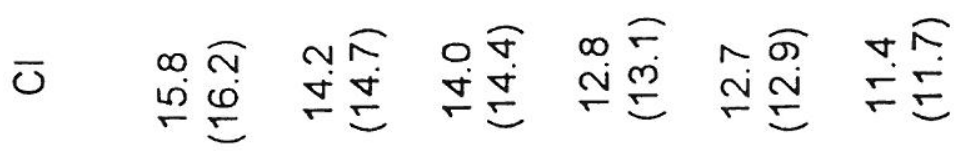

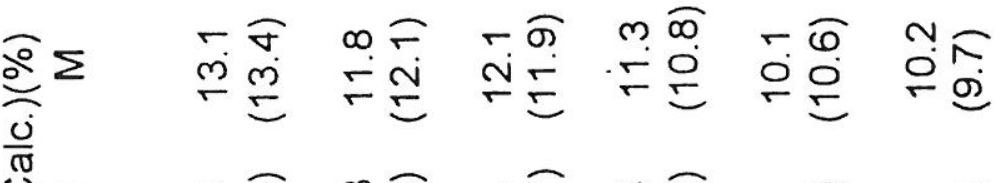

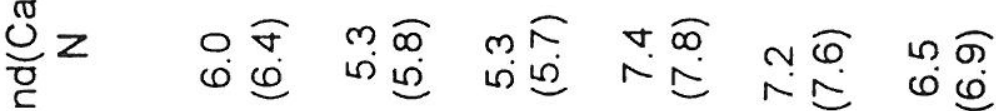

ริ

I में एं

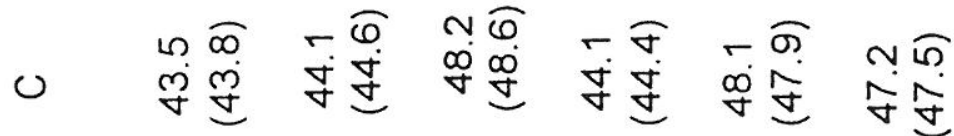

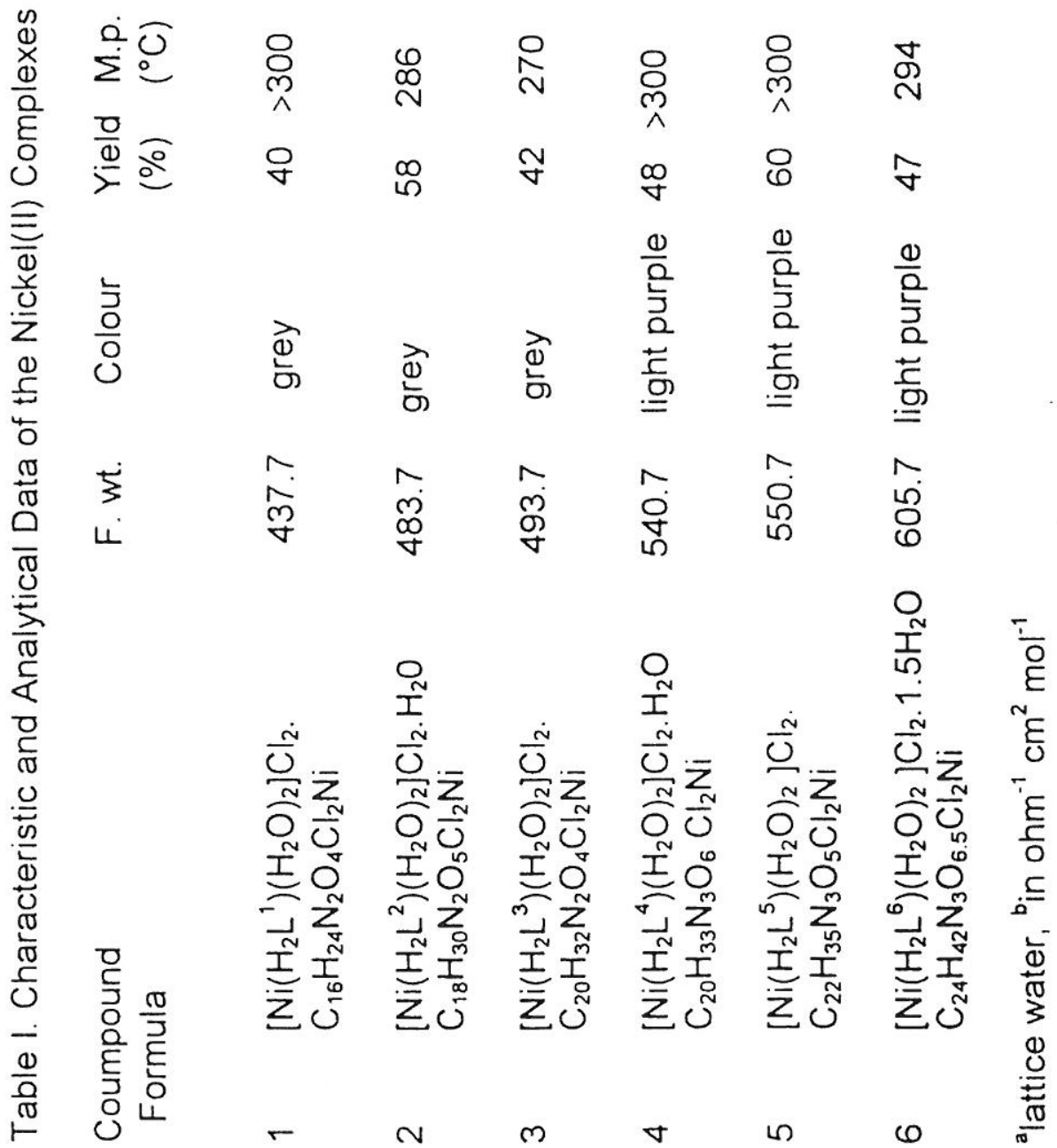




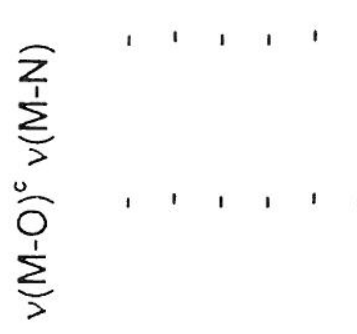

$33 E 333$

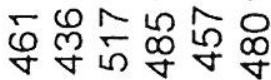
$33 E E 33$

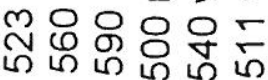

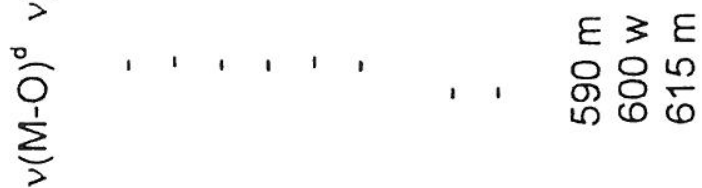
$\cong \quad \varepsilon \in E \varepsilon E \varepsilon$ $\sum_{>}^{1}$

$\sum_{>}^{1}$

उ 3

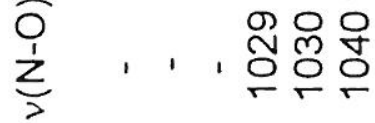

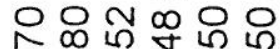
กิ

O $\backsim \backsim E E E$

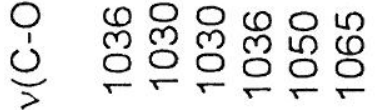
$\varepsilon \varepsilon \varepsilon$ 유유 는 $\varepsilon \varepsilon \varepsilon \varepsilon \backsim \varepsilon$ 인

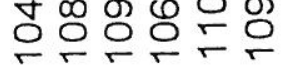

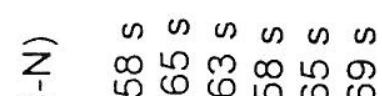

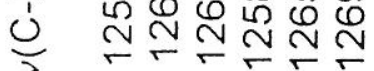
nus un us

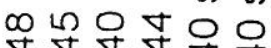

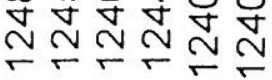
$\varepsilon E$ o

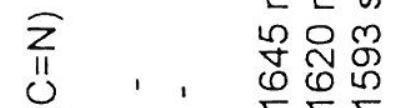
$\begin{array}{lll}n & \text { s } \\ 0 & 8 \\ 6 & 8 \\ 6 & 0\end{array}$ ผ $E \in E$ ำ 낭 $\varepsilon \varepsilon \varepsilon$ ㅇㅇㅇㅇㅇㅇ ติํํㅇ

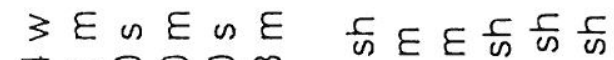

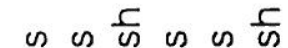
I Z Nָল্ল 궁융ㅇㅇㅇㅛ m

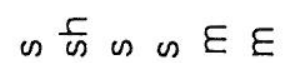

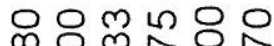

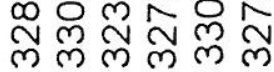
的 응ㅇㅇㅇㅇㅇㅇ ल्लm ल्m ल्m ल्m

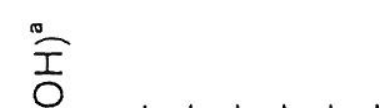

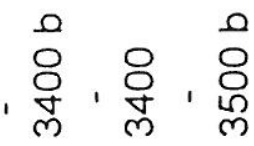

हัํํำ 
water, $\mathrm{NH}$ of amino group, $\mathrm{OH}$ of phenolic group and $\mathrm{OH}$ of oxime group (for complexes $4-6)^{9 \cdot 11}$. This suggests that these groups are coordinated to the metal ion in a non-deprotonated form, and they have undergone a shift to higher wave numbers in the complexes. The complexes 2, 4 and 6 contained lattice water, which is shown in their IR spectra as broad band $\mathrm{d}^{3}$ around $3400 \mathrm{~cm}^{-1}$.

In the complexes $4-6$ the $v(\mathrm{C}=\mathrm{N})$ band appear at a lower frequency $\mathrm{y}^{9-12.13}$ by 30 to 40 $\mathrm{cm}^{-1}$. The band assigned to $v(\mathrm{C}-\mathrm{N})$ is shifted by about 10 to $30 \mathrm{~cm}^{-1}$ towards the lower region in the complexes $4-6^{14}$. The spectra of the ligands show a band in the range 1030-1065 $\mathrm{cm}^{-1}$ assigned to $v(\mathrm{C}-\mathrm{O})$. In the complexes this band appears at higher freqencies by 10 to $50 \mathrm{~cm}^{-1}$. The band originated from the $\mathrm{N}-\mathrm{O}$ stretching vibration exhibits a shift of $10 \mathrm{~cm}^{-1}$ to the lower region in the complexes $4-6^{15}$. The coordination mode of the ligands is further supported by new frequencies occuring in the $690-400 \mathrm{~cm}^{-1}$ range which have been tentatively assigned to $v(\mathrm{Ni}-\mathrm{O})$ and $v(\mathrm{Ni}-\mathrm{N})$, respectively $\mathrm{y}^{11.16}$

The IR results show that the nickel atom is coordinated through the nitrogen atom of the amino group and the oxygen atom of the phenolic group and in addition through the oxygen atom of oxime group for complexes 4-6 without any deprotonation of the ligand.

\section{Thermal Analysis}

The TGA data are listed in Table III. They show that the thermal decomposition of the linear ligand $\mathrm{H}_{2} \mathrm{~L}^{1}$ occures at a slightly higher temperature than the tripodal ligand $\mathrm{H}_{2} \mathrm{~L}^{4}$, which is probably less thermodynamically stable than the former ligand ${ }^{17}$. The higher temperatures for the decomposition of the complexes, compared to those of the ligands, are consistent with the expectation that in the complexes, strong bonds are formed between the donor atoms of the ligands and the metal ion ${ }^{18}$. The complex 1 undergoes decomposition at a slightlylower temperature than the complex 4 . This indicates that the tripodal ligand gives the most stable complex with $\mathrm{Ni}(I I)$. 
Table III. Thermogravimetric Analysis Data

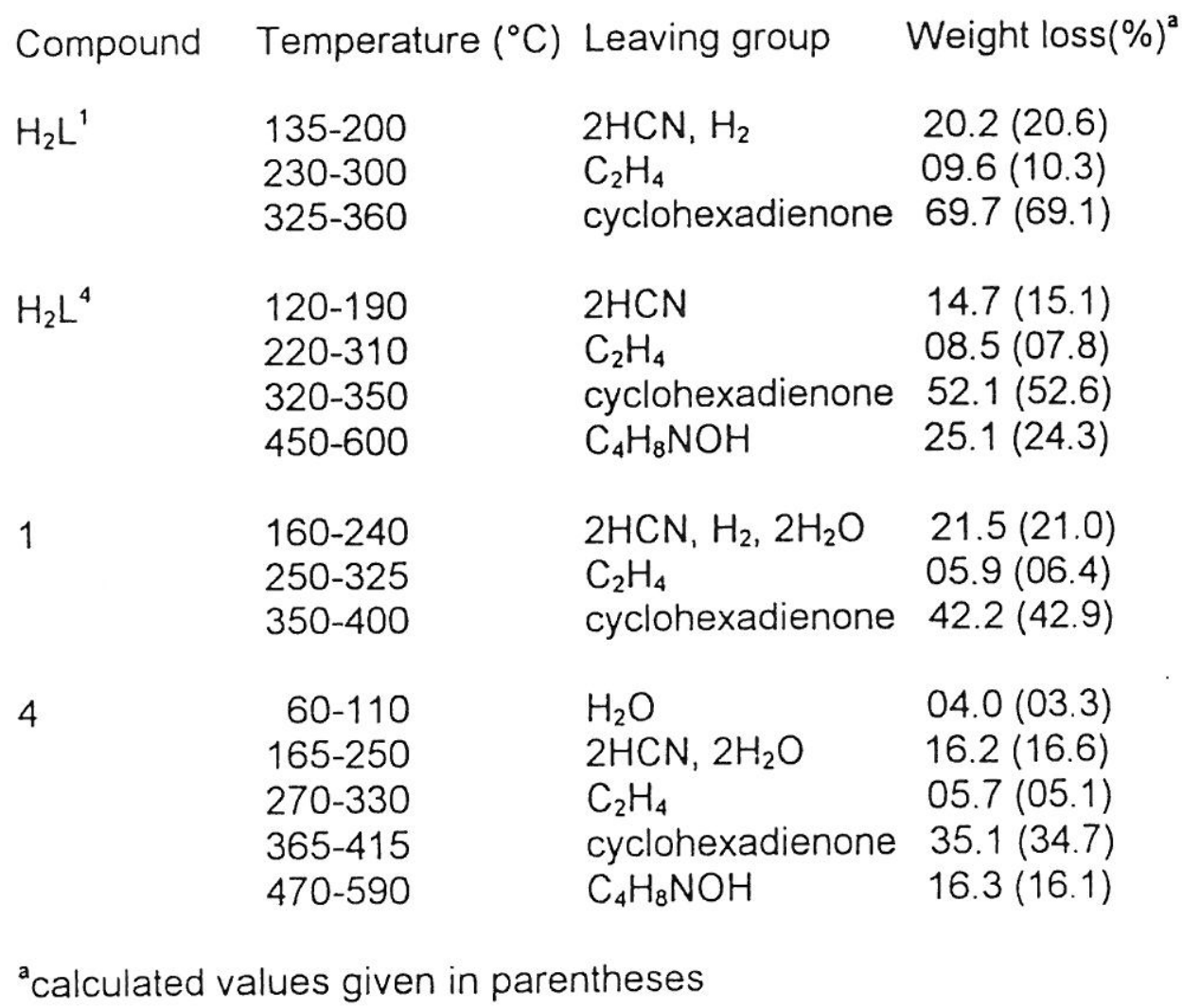

\section{Electronic Spectra}

The band positions and the calculated ligand field parameters are given in Table IV. The electronic spectra of nickel(II) complexes in DMSO solution exhibit a high intensity band in the near-UV region at $27000 \mathrm{~cm}^{-1}$, which is due to the intraligand transition $\pi \rightarrow \pi^{* 19}$ and three bands due to the ligand field transitions in the visible and near IR regions. These bands occuring in the ranges $9900-10400 \mathrm{~cm}^{-1}, 15800$ $16350 \mathrm{~cm}^{-1}$ and $20500-22900 \mathrm{~cm}^{-1}$ may correspond to ${ }^{3} \mathrm{~A}_{2 g} \rightarrow{ }^{3} \mathrm{~T}_{2 g}\left({ }^{3} \mathrm{~F}\right)\left(v_{1}\right),{ }^{3} \mathrm{~A}_{2 g} \rightarrow$ ${ }^{3} \mathrm{~T}_{1 g}\left(v_{2}\right)$ and ${ }^{3} \mathrm{~A}_{2 g} \rightarrow{ }^{3} \mathrm{~T}_{1 \mathrm{~g}}\left({ }^{3} \mathrm{P}\right)\left(v_{3}\right)$ transitions, respectively, assuming octahedral geometry around $\mathrm{Ni}(\mathrm{II})^{19-23}$. The ligand field parameters (10 Dq, $\mathrm{B}$, and $\beta$ ) have been calculated for these complexes (Table IV) using the equations suggested by $E$. König ${ }^{24}$. Their values indicate a covalent character of the metal-ligand bonds ${ }^{25}$. The $10 \mathrm{Dq}$ values obtained for the tripodal ligand field are slightly higher than those for the linear ligand field. This indicates that the tripodal ligand exerts the strongest ligand field. Also, it is noted that introducing C-alkyl groups onto the ligands affects the ligand field strength. As the $R$ group on the complexed ligand is 
Table IV. Magnetic, Electronic Spectral Data and Ligand Field Parameters of Nickel(II) Complexes

\begin{tabular}{|c|c|c|c|c|c|c|c|}
\hline \multirow[t]{2}{*}{ Compound } & \multirow[t]{2}{*}{$\mu_{\mathrm{eff}}^{\mathrm{a}}$} & \multicolumn{3}{|c|}{ Electronic transitions ${ }^{b}(\varepsilon)^{c}$} & \multirow{2}{*}{$\begin{array}{l}10 \mathrm{Dq} \\
\left(\mathrm{cm}^{-1}\right)\end{array}$} & \multirow{2}{*}{$\begin{array}{l}\mathrm{B} \\
\left(\mathrm{cm}^{-1}\right)\end{array}$} & \multirow[t]{2}{*}{$\beta$} \\
\hline & & $v_{1}$ & $v_{2}$ & $v_{3}$ & & & \\
\hline 1 & 3.34 & 990 & D(190) & 20 & & 778 & 0.748 \\
\hline 2 & 3.53 & $10150(12)$ & $16100(250)$ & $20800(440)$ & 10 & 767 & \\
\hline 3 & 3.31 & $10300(22)$ & $16250(300)$ & $22200(900)$ & & 753 & 0.724 \\
\hline 4 & 3.40 & $10100(06)$ & $16050(200)$ & $21300(500)$ & 10100 & 772 & 0.742 \\
\hline 5 & 3.45 & $10250(20)$ & $16200(320)$ & $21700(560)$ & 10250 & 758 & 0.728 \\
\hline 6 & 3.39 & $10400(30)$ & $16350(350)$ & $22900(920)$ & 10400 & 744 & 0.715 \\
\hline
\end{tabular}

a : magnetic moment in Bohr magnetons

$\mathrm{b}$ : wave number in $\mathrm{cm}^{-1}$

c : absorption molar coefficient in $\mathrm{mol}^{-1} \cdot 1 . \mathrm{cm}^{-1}$

varied from $\mathrm{H}$ to $\mathrm{C}_{2} \mathrm{H}_{5}$, the ligand field strength increases and the value of the nephelauxetic parameter decreases. This trend correlates with electron density at the nitrogen donor atom which shows the same order.

\section{Magnetic Measurements}

The magnetic moment values of the nickel(II) complexes are presented in Table IV. They show that the complexes studied are monomeric ${ }^{3.9}$. The $\mu_{\text {eff }}$ values lie within the range 3.00 - 3.50 B.M. reported for a six-coordinate high-spin $d^{8}$ nickel(II) ion ${ }^{20}$. In view of the above results, the following schemes may be proposed for the complexes.

In complexes 1-3 (Fig. 3), the ligands give a square planar arrangement of $\mathrm{N}_{2} \mathrm{O}_{2}$ donor groups around the nickel ion, the other axial sites being occupied by water molecules.

In complexes 4-6, the environment of the nickel ion is a distorted octahedron in which two cis-coordination sites are occupied by water molecules and the others by the tetradentate ligand. The construction of molecular models of the complexes shows that the ligand gives several conformations. The most probable structure is represented by Fig. 4 . 

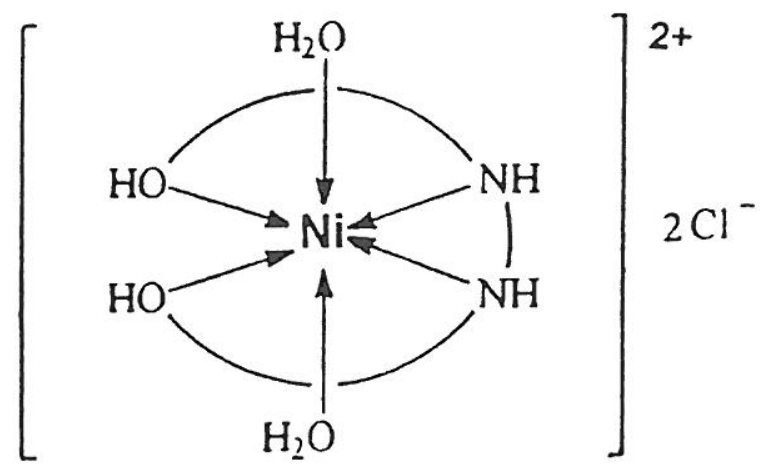

Fig. 3. Structural Scheme of $\mathrm{Ni}-\mathrm{H}_{2} \mathrm{~L}^{1-3}$ Complexes

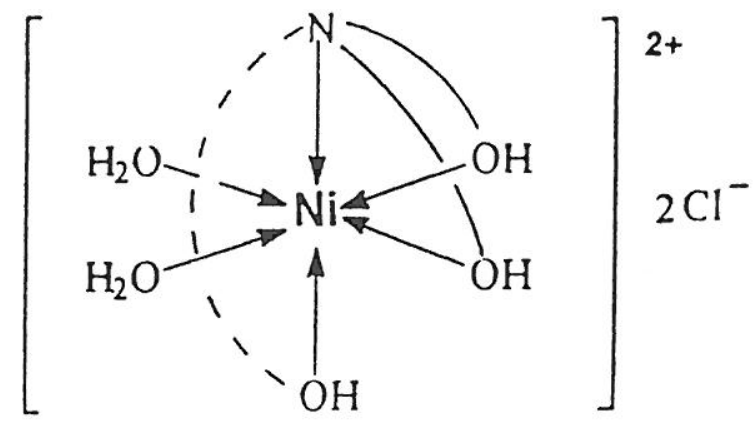

Fig. 4. Structural Scheme of $\mathrm{Ni}_{-} \mathrm{H}_{2} \mathrm{~L}^{4-6}$ Complexes

\section{Cyclic Voltammetry}

Voltammograms of the nickel(II) complexes were obtained in DMSO solution from +0.7 to $-1.6 \mathrm{~V}$ ( $v s$. SCE). The coulometric analysis indicates that in each of the processes one electron is transfered. Tripodal ligands $\mathrm{H}_{2} \mathrm{~L}^{4-6}$ undergo a oneelectron cathodic process which may be attributed to the reduction of the oxime group (Table V).

The cyclic voltammogram of $\mathrm{NiCl}_{2}$ compounds exhibits a begining of a cathodic wave at the limit of the cathodic potential used and its associated anodic peak was observed at $E_{p a}=-0.060 \mathrm{~V}$. The electrochemical results on reduction of complexes 1-6 at a sweep rate of $0.1 \mathrm{Vs}^{-1}$ are given in Table $\mathrm{V}$. The cyclic voltammogram of each complex exhibits one irreversible reduction process, in addition, a reduction is observed in the limits of the potential range studied for the complexes 4-6. By comparing the cyclic voltammograms of the complexes with those of ligands and that 
Table V. Electrochemical Data for the Reduction of Ligands, $\mathrm{NiCl}_{2}$ and $\mathrm{Ni}(\mathrm{II})$ Complexes $^{\mathrm{a}}$ in $0.1 \mathrm{M}$ TBAP in DMSO

$\begin{array}{lrcc}\text { Compound } & E_{p c}(V) & E_{p a}(V) & \Delta E(V) \\ \mathrm{H}_{2} \mathrm{~L}^{4} & <-1.600 & -0.300 & - \\ \mathrm{H}_{2} \mathrm{~L}^{5} & -1.540 & -0.240 & 1.300 \\ \mathrm{H}_{2} \mathrm{~L}^{6} & -1.400 & -0.260 & 1.140 \\ & & & \\ \mathrm{NiCl}_{2} & <-1.600 & -0.060 & - \\ & & & \\ 1 & -1.180 & -0.800 & 0.380 \\ 2 & -1.240 & -0.560 & 0.680 \\ 3 & -1.280 & -0.940 & 0.340 \\ & & & \\ 4 & -1.300 & +0.100 & 1.400 \\ & -1.500 & -0.300 & 1.200 \\ 5 & -1.220 & -0.100 & 1.120 \\ & -1.460 & -0.340 & 1.120 \\ 6 & -1.340 & -0.100 & 1.240 \\ & -1.540 & -0.300 & 1.240\end{array}$

${ }^{\mathrm{a}}$ Solute concentration $=10^{-3} \mathrm{M}$; scan rate $=100 \mathrm{mV} / \mathrm{s}$; $E_{p c}$ and $E_{p a}$ are the cahodic and anodic peak potentials, respectively; $\Delta E=E_{p a}-E_{p c} ; E_{1 / 2}=1 / 2\left(E_{p a}+E_{p c}\right)$

of $\mathrm{NiCl}_{2} .6 \mathrm{H}_{2} \mathrm{O}$ taken as reference, the cathodic process (see Fig. $5 \mathrm{a}, \mathrm{b}$ ) could be assigned to the reduction of $\mathrm{Ni}(\mathrm{II})$ to $\mathrm{Ni}(\mathrm{I})$.

The additional reduction shown in the case of complexes 4-6 (Fig. 5b) should correspond to a ligand-centered reduction ${ }^{26,27}$.

In all nickel(II) complexes, the metal-centered reduction agrees with an irreversible electron-transfer. Further, in the negative potential range and on the cathodic scan, the peak observed for complexes 1-6 is intense. But on the reverse sweep, the anodic wave related with the cathodic peak is of medium intensity. This indicates that a chemical reaction occurs after the anodic oxydation of the complexes ${ }^{20.28 .29}$. It was observed in this study that the reduction potentials for the $\mathrm{Ni}(\mathrm{II/I})$ couple of the complexes are sensitive to the electronic effect of the $R$ group on the coordinated ligand. These potentials shift cathodically on going from complex 1 to 3 with linear ligands and from complex 4 to 6 with tripodal ligands. As the substituent $R$ in the 


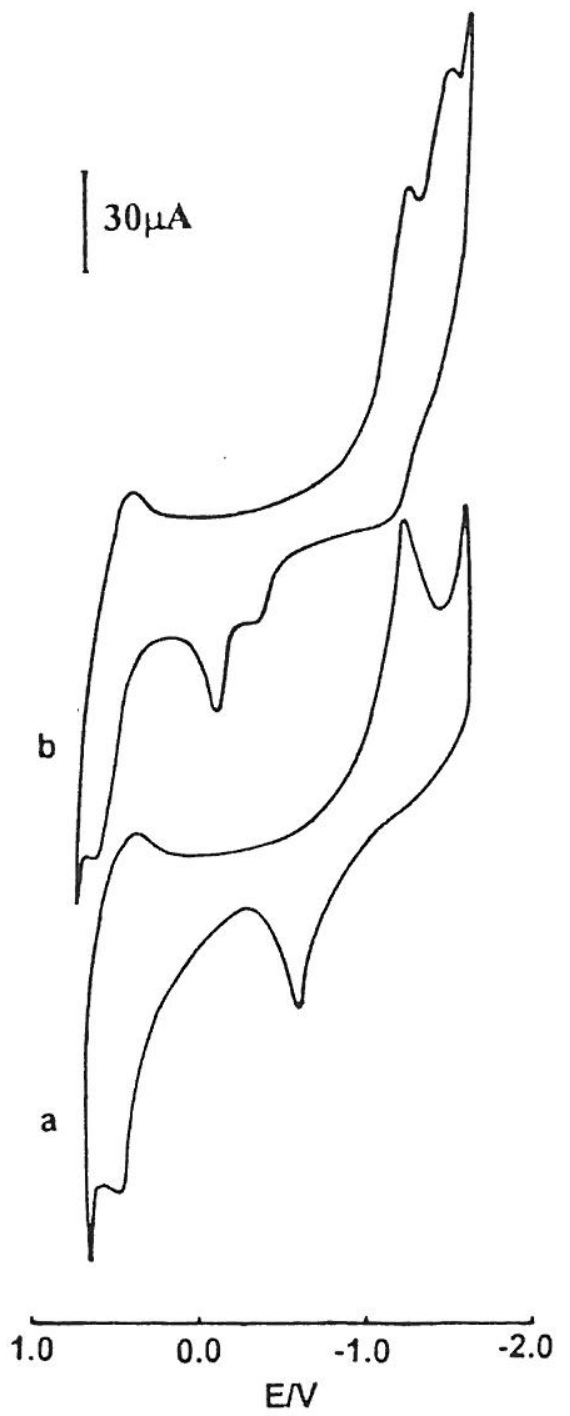

Fig. 5. Cyclic Voltammograms for the Complexes,

(a) $\left[\mathrm{Ni}\left(\mathrm{H}_{2} \mathrm{~L}^{2}\right)\left(\mathrm{H}_{2} \mathrm{O}\right)_{2}\right] \mathrm{Cl}_{2}$. (b) $\left[\mathrm{Ni}\left(\mathrm{H}_{2} \mathrm{~L}^{5}\right)\left(\mathrm{H}_{2} \mathrm{O}\right)_{2}\right] \mathrm{Cl}_{2}$.

in DMSO (0.1 M TBAP); Scan Rate $=100 \mathrm{mV}$.

ligand is varied from $\mathrm{H}$ to $\mathrm{C}_{2} \mathrm{H}_{5}$, the electron density on nickel ion increases, this increases the difficulty to reduce the metal center ${ }^{3,13,30,31}$.

We have noted in our previous study on $\mathrm{Cu}(\mathrm{II})$ with the same ligands ${ }^{7}$ that $\mathrm{Cu}(\mathrm{I})$, which favors a tetrahedral geometry ${ }^{32}$, is more stabilized as the $\mathrm{R}$ groups in the complexed ligands are changed from $\mathrm{H}$ to $\mathrm{C}_{2} \mathrm{H}_{5}$ because the distortion of the unit $\mathrm{CuN}_{2} \mathrm{O}_{2}$ in the complexes increases in the same order. In the present study the reduction potentials for the $\mathrm{Ni}(\mathrm{II} / \mathrm{I})$ couple of the complexes were more cathodic on going from hydrogen to ethyl and a subsequent destabilisation of $\mathrm{Ni}(\mathrm{I})$ state occured. This shows that these potentials are not sensitive to steric effects of the substituent 
Table VI. Electrochemical Data for the Oxidation of $\mathrm{Ni}(\mathrm{II})$ Complexes $^{\mathrm{a}}$ in $0.1 \mathrm{M}$ TBAP in DMSO

$\begin{array}{llll}\text { Compound } & E_{p a}(V) & E_{p c}(V) & \Delta E(V) \\ 1 & +0.560 & +0.400 & 0.160 \\ 2 & +0.500 & +0.360 & 0.140 \\ 3 & +0.440 & +0.300 & 0.140 \\ 4 & & & \\ 5 & +0.640 & +0.460 & 0.180 \\ 6 & +0.600 & +0.400 & 0.200 \\ & +0.550 & +0.350 & 0.200\end{array}$

a Solute concentration $=10^{-3} \mathrm{M}$; scan rate $=100 \mathrm{mV} / \mathrm{s}$;

$E_{p a}$ and $E_{p c}$ are the anodic and cathodic peak potentials, respectively; $\Delta E=E_{p a}-E_{p c} ; E_{1 / 2}=1 / 2\left(E_{p a}+E_{p c}\right)$

$\mathrm{R}$ in the ligand because there is not a significant structural change between the oxydized $\left(3 d^{8}\right)$ and reduced $\left(3 d^{9}\right)$ species ${ }^{26,33}$.

More positive potential values were found for the complexes with tripodal ligands. A construction of molecular models of these complexes makes clear that they have a large size, consequently they can more easily accomodate the size increase expected with the addition of an antibonding $d$ electron. Potential values of the oxidation process of the nickel complexes are summarized in Table VI. They suggest an irreversible process for each complex. Further, they show that the complexes 1-3 are easier to oxidize than complexes 4-6. This is probably due to the fact that the small ionic radius of nickel(III) would fit better into the smaller size of linear ligands.

The electrochemical data on the oxidation of the complexes are consistent with the spectral data. In the complexes the ligand field strength increases from $\mathrm{R}=\mathrm{H}$ to $\mathrm{R}=\mathrm{C}_{2} \mathrm{H}_{5}$, this facilitates the oxidation of the metal center ${ }^{5.34}$.

\section{ACKNOWLEDGEMENT}

We thank the laboratory of Professor F. Kermiche (Institut de Chimie, Universite des Sciences et de la Technologie Houari Boumediene, Alger) for making possible the electrochemical measurements. 


\section{REFERENCES}

1. J. R. Lancaster, Jr., "The Bioinorganic Chemistry of Nickel", VCH, Weinheim (1988).

2. I. A. Gennaro and E. Vianello, J. Chem. Soc. Dalton Trans, 2091 (1993).

3. J. Costamagna, J. Vargas, R. Latorre, A. Alvarado and G. Mena, Coord. Chem. Rev., 119, 67 (1992).

4. C. J. Burrows, J. G. Mulki, G. T. Poulter and S. E. Rokita, Acta Chem. Scand., 50, 337 (1996).

5. A. L. Nivorozhkin, H. Toftlund, P. L. Jorgensen and L. E. Nivorozhkin, J. Chem. Soc. Dalton. Trans., 1215 (1996).

6. A. I.Vogel, "Textbook of Quantitative Inorganic Analysis", Longmans, London, p. 433 (1978).

7. S. Djebbar-Sid, O. Benali-Baitich and J. P. Deloume, Polyhedron, 16, 2175 (1997).

8. W. J. Geary, Coord. Chem. Rev., I, 81 (1971).

9. K. K. Narang and M. K. Singh, Inorg. Chim. Acta, 131, 245 (1987).

10. K. Lal, J. Singh and S. P. Gupta, Acta Chim. Acad. Sci. Hung., 95, 233 (1977).

11. M.S. Islam and M. Masir Uddin, Polyhedron, 12, 423 (1993).

12. J. A. Castro, J. Romero, J. A. Garcia-Vasquez and A. Sousa, Polyhedron, 12, 31 (1993).

13. A. E. Tai, E. J. Lien, M. Mc Lai and T. A. Khwaja, J. Med. Chem., 27, 236 (1984).

14. M. Lalia-Kantouri and M. Hartophylles, Polyhedron, 11, 789 (1992).

15. F. Lioret, I. Castro, J. Faus, M. Julve and J. Latorre, New J.Chem.,15, 47 (1991).

16. K. K. Narang, M. K. Singh, K. B. Singh and R. A. Lal, Synth. React. Inorg. MetOrg. Chem., 26, 582 (1996).

17. L. S. Gonzales and K. S. Nagaraja, Polyhedron, $\underline{6}, 1637$ (1987).

18. Xu Pengfei, Xu Zhuguo, Liu Suyan and Wu Shaozu, Synth. React. Inorg. MetOrg. Chem., 26, 1443 (1996).

19. J. Csaszar, Acta Chim. Hung., 128, 255 (1991).

20. K. G. Ragunathan and P. K. Bharadwaj, J. Chem. Soc. Dalton Trans., 2420 (1992). 
21. M. Shakir, A. K. Mohamed and O. S. M. Nasman, Polyhedron, 15 3490 (1996).

22. S. Chandrasekhar and A. McAuley, J. Chem. Soc. Dalton Trans., 2969 (1992).

23. M. A. Mesubi and B. A. Omotowa, Synth. React. Inorg. Met.-Org. Chem., 23, 223 (1993).

24. E. König, Structure and Bonding, Berlin, $\underline{9}, 181$ (1971).

25. M. Shakir, S. P. Varkey and P. S. Hameed, Polyhedron, 13, 1355 (1994).

26. G. Wilkinson, "Comprehensive Coordination Chemistry", Pergamon Press, Oxford, Vols 5,6. p. 726, 494 (1987).

27. F. Azevedo, M. A. A. F. de C. T. Carrondo, B. de Castro, M. Convery, D. Domingues, C. Freire, M. T. Duarte, K. Nielsen and I. C. Santres, Inorg. Chim. Acta, 43, 219 (1994).

28. A. Kotocova, D. Valigura and J. Sina, J. Coord. Chem., 24, 363 (1991).

29. Feng Hio, R. L. Webb, C. Kelly, M. L. Mino, B. Woodworth and E. L. Blinn, Inorg. Chim. Acta, 234, 8 (1995).

30. A. J. Elliot, G. A. Lawrance and G. Wei, Polyhedron, 12, 851 (1993).

31. Y. Nonaka and K. Hamada, Bull. Chem. Soc. Jpn., 54, 3187(1981).

32. V. V. Pavlishchuk, P. E. Strizhak and K. B. Yatsimirskii, Inorg. Chim. Acta, 151 133 (1988).

33. A. Arquero, M. A. Mendiola and P. Souza, Polyhedron, 15. 1662 (1996).

34. Shin-Geol Kang, Mi-Seon Kim, Seong-Jin Kim and Kiseok Ryu, Polyhedron, 15, 1839 (1996).

Received: 25 March 1997

Accepted: 16 June 1997
Referee I: H. N. Po

Referee II: D. Dollimore 